\title{
Response of C2C12 Myoblasts to Hypoxia: The Relative Roles of Glucose and Oxygen in Adaptive Cellular Metabolism
}

\author{
Wei Li, ${ }^{1}$ Zhen-Fu Hu, ${ }^{2}$ Bin Chen, ${ }^{3}$ and Guo-Xin $\mathrm{Ni}^{3}$ \\ ${ }^{1}$ Clinical Medicine Education Center, Nanfang Hospital, Southern Medical University, Guangzhou 510515, China \\ ${ }^{2}$ Department of Plastic Surgery, Nanfang Hospital, Southern Medical University, Guangzhou 510515, China \\ ${ }^{3}$ Department of Orthopaedics and Traumatology, Nanfang Hospital, Southern Medical University, Guangzhou 510515, China
}

Correspondence should be addressed to Guo-Xin Ni; nigx69@163.com

Received 3 July 2013; Revised 22 September 2013; Accepted 23 September 2013

Academic Editor: Joohun Ha

Copyright (C) 2013 Wei Li et al. This is an open access article distributed under the Creative Commons Attribution License, which permits unrestricted use, distribution, and reproduction in any medium, provided the original work is properly cited.

\begin{abstract}
Background. Oxygen and glucose are two important nutrients for mammalian cell function. In this study, the effect of glucose and oxygen concentrations on $\mathrm{C} 2 \mathrm{C} 12$ cellular metabolism was characterized with an emphasis on detecting whether cells show oxygen conformance (OC) in response to hypoxia. Methods. After $\mathrm{C} 2 \mathrm{C} 12$ cells being cultured in the levels of glucose at $0.6 \mathrm{mM}$ (LG), $5.6 \mathrm{mM}(\mathrm{MG})$, or $23.3 \mathrm{mM}(\mathrm{HG})$ under normoxic or hypoxic (1\% oxygen) condition, cellular oxygen consumption, glucose consumption, lactate production, and metabolic status were determined. Short-term oxygen consumption was measured with a novel oxygen biosensor technique. Longer-term measurements were performed with standard glucose, lactate, and cell metabolism assays. Results. It was found that oxygen depletion in normoxia is dependent on the glucose concentration in the medium. Cellular glucose uptake and lactate production increased significantly in hypoxia than those in normoxia. In hypoxia the cellular response to the level of glucose was different to that in normoxia. The metabolic activities decreased while glucose concentration increased in normoxia, while in hypoxia, metabolic activity was reduced in LG and MG, but unchanged in HG condition. The OC phenomenon was not observed in the present study. Conclusions. Our findings suggested that a combination of low oxygen and low glucose damages the viability of $\mathrm{C} 2 \mathrm{C} 12$ cells more seriously than low oxygen alone. In addition, when there is sufficient glucose, C2C12 cells will respond to hypoxia by upregulating anaerobic respiration, as shown by lactate production.
\end{abstract}

\section{Background}

Oxygen and glucose are crucial for cellular respiration. Glycolysis underlies both anaerobic and aerobic respiration, but aerobic respiration provides a greater yield of ATP per molecule of glucose if oxygen is available. The ability of a mammalian cell to gauge the oxygen concentration in its environment and to protect itself through internal regulation is known as oxygen sensing $[1,2]$. Normal cellular function depends on the supply of oxygen, that is, sufficient for metabolic needs. If the oxygen supply does not match the cellular energy demands, adaptive mechanisms would occur to compensate. However, once such adaptive mechanisms are insufficient to prevent cellular hypoxia, an increase in anaerobic synthesis of ATP would be expected to meet the demand [3]. Under anoxic condition, the rate of glycolysis in mammalian cells is considered to be insufficient to maintain intracellular concentrations of ATP.

The conventional view that a decrease in oxygen consumption will only be caused by oxygen limitation at mitochondria is now challenged by a phenomenon described as oxygen conformance (OC), by which oxygen consumption declines as the oxygen supply is reduced without either a loss of cellular viability or compensatory anaerobic energy production $[4,5]$. OC has been reported in hepatocytes, skeletal muscle, and cardiomyocytes [6-9]. In these cell types, oxygen consumption under condition of low oxygen concentration is reduced to maintain cellular survival without an increase in anaerobic energy production.

$\mathrm{C} 2 \mathrm{C} 12$ murine myoblast has been widely applied to in vitro studies on skeletal muscle damage, regeneration, and differentiation, as well as chemical, electrical and mechanical 
stimulation due to the cell line's rapid growth, ease of culture, and sensitivity to manipulations [10-18]. In addition, it has been extensively used for the production of $3 \mathrm{D}$ tissueengineered muscle [19-24]. Previously, it was declared that the $\mathrm{C} 2 \mathrm{C} 12$ cell line exhibited OC behavior [25]. More recently, Gawlitta et al. [26] investigated how the metabolism, including glucose utilization, of $\mathrm{C} 2 \mathrm{C} 12$-engineered skeletal muscle is influenced by ischemic factors and suggested that during hypoxia, anaerobic metabolism is adopted, resulting in lactic acid accumulation, and cellular metabolism is downregulated by the occurrence of OC. However, in these studies, the OC rate of $\mathrm{C} 2 \mathrm{C} 12$ cell, which is a key parameter to verify the occurrence of OC, was not determined. Therefore, to further understand the response of myoblast to hypoxia, in the present study, the aerobic and anaerobic respirations in $\mathrm{C} 2 \mathrm{C} 12$ murine skeletal myoblast were investigated by measuring oxygen consumption, glucose consumption, lactate production, and metabolic activity in different glucose concentrations and under conditions of normoxia and hypoxia.

\section{Material and Methods}

2.1. Cell Culture. C2C12 murine skeletal muscle myoblasts (passages 15-30, ECACC, Salisbury, UK) were cultured in tissue culture flasks (Sarstedt), in a humidified, $37^{\circ} \mathrm{C}, 5 \% \mathrm{CO}_{2}$ incubator and passaged every 2-3 days at 80-90\% confluency. Growth media (GM) for cell propagation was DMEM (4.5 g/L glucose, containing GlutaMAX) to which sterile supplements were added as follows (per $100 \mathrm{~mL}$ ): $10 \mathrm{~mL}$ FCS (gammairradiated, containing $1.16 \mathrm{~g} / \mathrm{L}$ glucose; BioSera), $1 \mathrm{~mL}$ sodium pyruvate $(100 \mathrm{mM}), 0.5 \mathrm{~mL}$ Penicillin $(10,000 \mathrm{U} / \mathrm{mL})$, streptomycin $(10,000 \mathrm{ug} / \mathrm{mL})$, and $1 \mathrm{~mL}$ uridine.

For all experiments, media were changed to experiment media (EM), which was phenol red-free DMEM (D5030, Sigma, plus $3.7 \mathrm{~g} / \mathrm{L}$ sodium bicarbonate), supplemented as GM but with the addition of $2 \mathrm{~mL}$ glutamine $(200 \mathrm{mM})$ and the omission of uridine. Glucose was added to EM prior to supplementation at $0 \mathrm{~g} / \mathrm{L}$ (low glucose, LG), $1 \mathrm{~g} / \mathrm{L}$ (medium glucose, $\mathrm{MG}$ ), and $4.5 \mathrm{~g} / \mathrm{L}$ (high glucose, $\mathrm{HG}$ ). Due to the presence of glucose in the supplemental FCS, the final glucose concentration in experiment media was 0.6 (LG), 5.6 (MG), and 23.3 (HG) mM, respectively. EM were equilibrated overnight in a standard $5 \% \mathrm{CO}_{2}$ incubator at $37^{\circ} \mathrm{C}$ before being added to cells. Tissue culture reagents were purchased from Invitrogen unless otherwise stated; chemicals were purchased from Sigma unless otherwise stated.

\subsection{Oxygen Measurement Using BD Biosensor System. Two} hundred microlitre aliquots of cell suspensions, at 3 densities of 50,000,100,000 and 200,000 cells/mL, swere transferred into 96-well oxygen biosensors (Becton Dickinson Bioscience, Oxford, UK). The loaded biosensors were transferred immediately to the $5 \% \mathrm{CO}_{2}$ humidified environment of a standard cell culture incubator referred to the normoxic condition in this study. As for hypoxia condition, biosensors loaded as above were transferred into a humidified incubator (Innova CO-48) set to maintain a $1 \% \mathrm{O}_{2}, 5 \% \mathrm{CO}_{2}, 37^{\circ} \mathrm{C}$ environment. The oxygen concentration of the samples was recorded from the base of the wells by scanning the biosensor plate using a fluorescence plate reader (Fluoroskan Ascent FL, Thermo Lab systems) at hourly intervals over a 6-hour period.

2.3. Biosensor System Calculations. The oxygen biosensor (BD Biosciences, Oxford, UK) consists of a 96-well plate with an oxygen sensitive dye embedded within a gas permeable silicon matrix immobilized at the base of each well. Oxygen quenches the ability of the dye to fluoresce in a concentrationdependent manner. The fluorescence intensity at the base of each well was read using excitation and emission filters of 485 and $595 \mathrm{~nm}$, respectively. The quenching behavior of the biosensor fluorophores is described by a mathematical model, namely, the Stern-Volmer equation:

$$
\frac{I_{0}}{I}=1+K_{\mathrm{sv}} \times\left[\mathrm{O}_{2}\right]
$$

where $\left[\mathrm{O}_{2}\right]$ is the oxygen concentration, $K_{\mathrm{sv}}$ is the fluorophore quenching constant, $I$ is the normalized fluorescence intensity at $\left[\mathrm{O}_{2}\right]$, and $I_{0}$ is the normalized fluorescence intensity recorded at the reference condition (zero oxygen). The value of $K_{\mathrm{sv}}$ can be calculated from the ratio of the fluorescence intensity recorded from two reference conditions. In the present work, these correspond to a cell-free medium sample that had equilibrated with the incubator atmosphere, referred to as the ambient control $\left[\mathrm{O}_{2}\right]_{A}$ and a zero oxygen control that consisted of $100 \mathrm{mM}$ sodium sulphite, such that

$$
K_{\mathrm{sv}}=\frac{I_{0} / I_{A}-1}{\left[\mathrm{O}_{2}\right]_{A}},
$$

where $I_{0}$ is the normalized fluorescence intensity in the zero oxygen control and $I_{A}$ is the normalized fluorescence intensity a $\left[\mathrm{O}_{2}\right]_{A}$. The values $I_{0}$ and $I_{A}$ were measured using the biosensor, where the value of $\left[\mathrm{O}_{2}\right]_{A}$ was calculated using Henry's law for the equilibrium distribution of oxygen between the atmosphere and water, and defined as (3)

$$
\left[\mathrm{O}_{2}\right]_{A}=\frac{\alpha}{V_{m}} \times \mathrm{PO}_{2}
$$

where $\left[\mathrm{O}_{2}\right]_{A}$ is the concentration of oxygen in solution [moles/L], $\alpha$ is the solubility coefficient of oxygen expressed as volume of gas per volume of water, $V_{m}$ represents the molar volume of oxygen at standard temperature $\left(0^{\circ} \mathrm{C}\right)$ and pressure (1 Atm), and $\mathrm{PO}_{2}$ is the partial pressure of oxygen in the atmosphere. According to Avogadro's theory, the solubility coefficient of oxygen in water is 0.024 and the value of $V_{m}$ for oxygen is $22.4 \mathrm{~L}$ at $37^{\circ} \mathrm{C}$. The partial pressure of oxygen in air at sea level $(0.210 \mathrm{~atm})$ is reduced to $0.186 \mathrm{~atm}$ under the test conditions by the additional $\mathrm{CO}_{2}(0.050 \mathrm{~atm})$ and water vapor $(0.062 \mathrm{~atm})$ in the incubator atmosphere. Substituting these values into (3) yields the oxygen concentration in the ambient control of $200 \mu \mathrm{M}$ and in the $1 \%$ oxygen $\mathrm{CO}_{2}$ incubator control of $10.7 \mu \mathrm{M}$ [27]. 
2.4. Glucose and Lactate Measurement. For each cell density supplied with HG medium, additional replicates were prepared as above but in standard separate 96-well plates and cultured for up to 72 hours to provide samples for glucose and lactate determinations. The medium was aspirated at 24hour intervals, transferred immediately to prelabeled microcentrifuge tubes on ice, and then frozen prior to subsequent determination of the glucose and lactate concentrations, as below.

Standard protocols for glucose and lactate measurements were followed. In brief, glucose concentrations in the medium were determined using the infinity glucose assay reagent (Sigma Diagnostics). Infinity reagent contains hexokinase, glucose-6-phosphate dehydrogenase, and NAD ${ }^{+} .240 \mu \mathrm{L}$ of reagent was added to $12 \mu \mathrm{L}$ aliquots of each diluted sample, preculture media controls, or glucose standard solutions in duplicate and the reactions were incubated at $37^{\circ} \mathrm{C}$ for 10 minutes before recording the absorbance at $340 \mathrm{~nm}$ using a plate reader. For lactate measurements, $10 \mathrm{mg}$ of $\beta \mathrm{NAD}^{+}$ was reconstituted with $2 \mathrm{~mL}$ glycine buffer, $4 \mathrm{~mL}$ water, and $0.1 \mathrm{~mL} \mathrm{LDH}$ suspension. $140 \mu \mathrm{L}$ of the reconstituted $\beta \mathrm{NAD}^{+}$ was added to $6 \mu \mathrm{L}$ of sample, lactate standards, sand preculture media controls in duplicate and incubated at $37^{\circ} \mathrm{C}$ for 30 minutes before the absorbance was recorded at $340 \mathrm{~nm}$. Samples that exceeded the standard curve were diluted and remeasured.

2.5. Alamar Blue Assay. The Alamar Blue assay is a commercially available product (Serotec Ltd., Oxford, UK) as an indicator of cellular metabolic status. For each of the three cell densities, additional replicates were prepared as above in standard separate 96-well plates and cultured for up to 48 hours. Alamar Blue reagent was added to cell culture media at a concentration of $10 \%(\mathrm{v} / \mathrm{v})$ then incubated in a standard $5 \% \mathrm{CO}_{2}$ incubator at $37^{\circ} \mathrm{C}$ for 4 hours then fluorescence was measured (excitation wavelength $570 \mathrm{~nm}$ and emission wavelength at $590 \mathrm{~nm}$, Fluoroskan Ascent FL; Thermo Lab systems).

2.6. Statistical Analysis. All data are presented as mean \pm standard deviation. The effect of different glucose concentrations (LG, MG, and HG) and of the cultivation environment (either normoxic or hypoxic) on the metabolic status of $\mathrm{C} 2 \mathrm{C} 12$ cells was analyzed simultaneously by one-way analysis of variance (ANOVA) performed with GraphPad Prism version 5 . Individual comparisons were subsequently made between each glucose concentration using a Bonferroni post tests. Statistical significance is indicated as $P>0.05$ (non-significant, ns); $P<0.05\left(^{*}\right) ; P<0.01\left(^{* *}\right)$; and $\left.P<0.001{ }^{* * *}\right)$.

\section{Results}

3.1. Effect of Glucose Concentration on Oxygen Consumption of C2C12 Cells. Figures 1 and 2 showed oxygen consumption of $\mathrm{C} 2 \mathrm{C} 12$ cells of various densities cultured with different glucose concentrations under either normoxic or hypoxic condition. Under normoxic condition, a monotonic reduction in oxygen concentration was observed over six hours, and this oxygen consumption was proportional to cell density for cells cultured at LG level (Figure 1(a)). At either MG or HG level, the oxygen consumption was similar for cells cultured at densities of $0.5 \times 10^{5}$ and $1 \times 10^{5}$ cells $/ \mathrm{mL}$ but higher than that at a density of $2 \times 10^{5}$ cells $/ \mathrm{mL}$ (Figures 1(b) and 1(c)). The highest oxygen consumption was observed with cells cultured in LG conditions at a density of $2 \times 10^{5}$ cells $/ \mathrm{mL}$.

Under normoxic condition, a linear model was fitted for each experimental variable to the data from 1 to $6 \mathrm{hrs}$. OC rate was determined from the gradient of this line and converted to oxygen moles/hour/cell (Figure 2). The rate did not appear to be substantially affected by the cell density; however, when comparing cells cultured at density of $1 \times$ and $2 \times 10^{5}$ cells $/ \mathrm{mL}$, it was found that $\mathrm{OC}$ rate decreased with the increase glucose concentration.

Figures 1(d)-1(f) presented data from experiments concerning hypoxia where the biosensor plates were cultured in conditions of $1 \%$ oxygen but transferred to the $21 \%$ oxygen environment of room air at hourly interval for fluorescence measurement. The measurement procedure took around 3 minutes during which the biosensor plates were equilibrating with $21 \%$ oxygen instead of $1 \%$ oxygen. Consequently, the recorded fluorescence should be normalized to an intermediate value between $1 \%$ (incubation condition) and $21 \%$ (measurement condition), which is not precisely known. Due to this technical limitation, the oxygen concentrations shown in the $y$-axis labels were somewhat arbitrary (Figures 1(d)$1(\mathrm{f})$ ) and further analysis, such as calculation of oxygen consumption rates, was therefore not attempted. However, trends may still be identified from these data; for example, Figure 1(d) revealed clear differences between cells cultured at different densities, which are likely to be attributed to oxygen consumption by the cells. A similar relationship was suggested to that observed in normoxia between oxygen concentration, cell density, and glucose concentration (Figures $1(d)-1(f))$.

\subsection{Effect of Hypoxia on Glucose Uptake and Lactate Produc-} tion of $\mathrm{C} 2 \mathrm{C} 12$ Cells. Glucose uptake and lactate production were measured for cells cultured at three different densities in normoxia or hypoxia for 24,48 , and 72 hours (Figure 3 ). The effect of supplemental glucose was not examined and all cells were cultured in HG conditions.

In normoxia, glucose uptake was similar for three cell densities at 24 and $48 \mathrm{hrs}$ (Figures 3(a) and 3(b)) but was clearly proportional to cell density by $72 \mathrm{hrs}$ (Figure $3(\mathrm{c}))$. Lactate production was proportional to cell density at 24, 48 and 72 hours (Figures 3(d)-3(f)). In hypoxia, the same patterns were seen as for normoxia; however, both glucose uptake and lactate production were consistently higher in hypoxia than in normoxia. Glucose uptake and lactate production increased sharply over the three day-time course of the experiment, and such increase was greater in hypoxia than that in normoxia (Figure 3). 


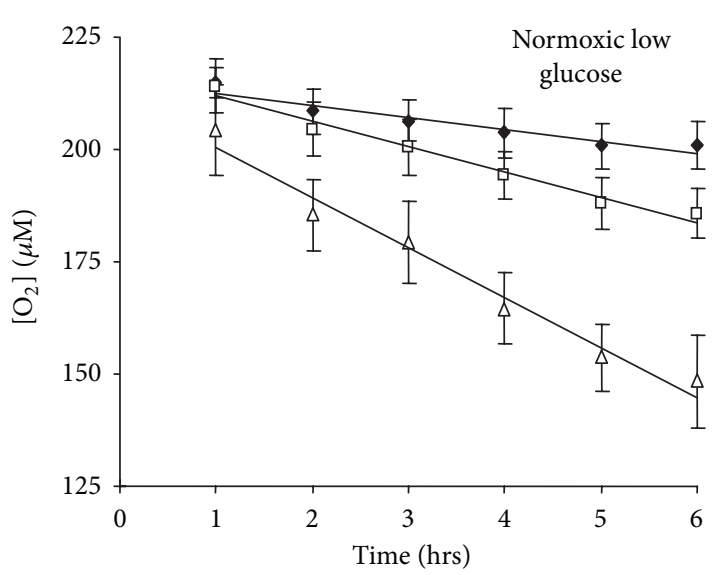

(a)

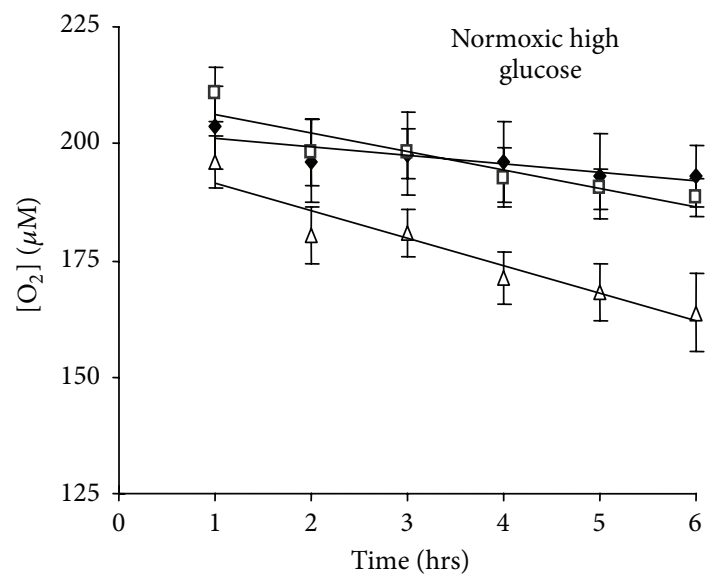

(c)

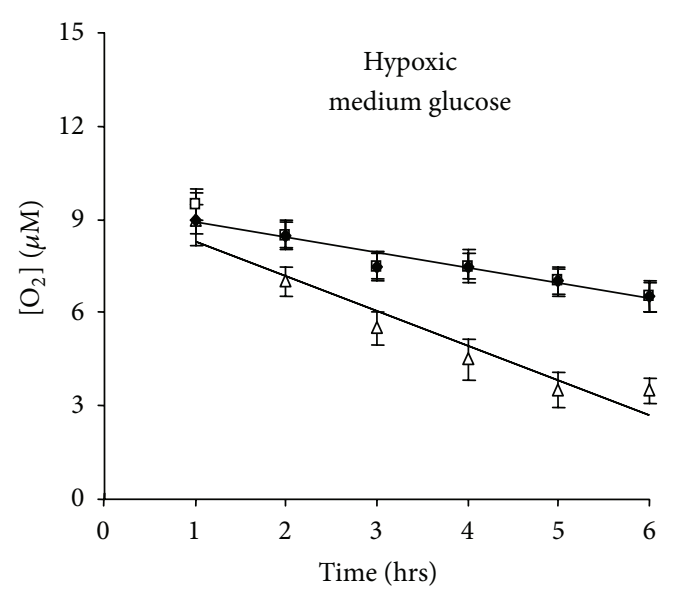

(e)

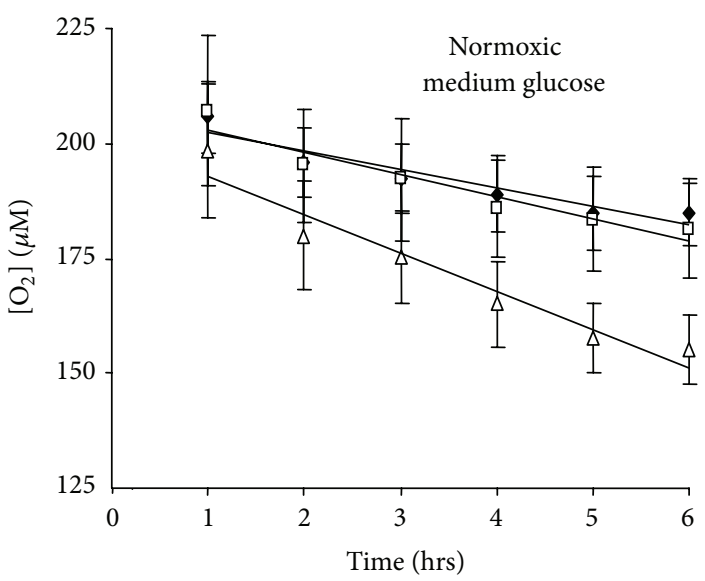

(b)

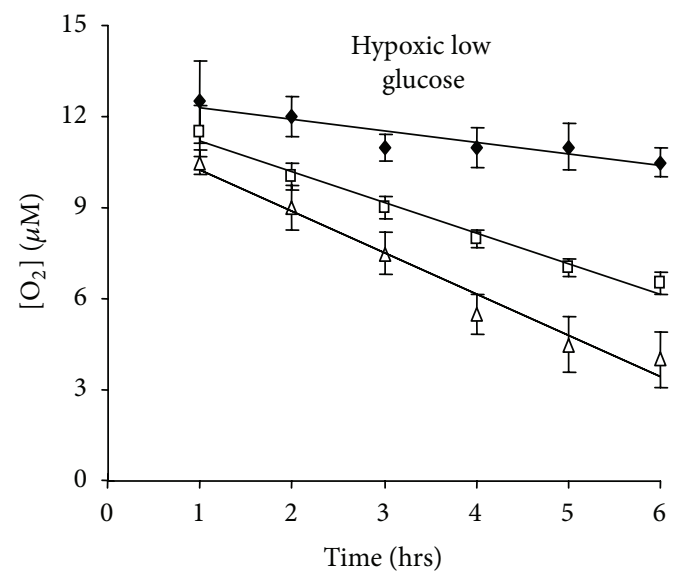

(d)

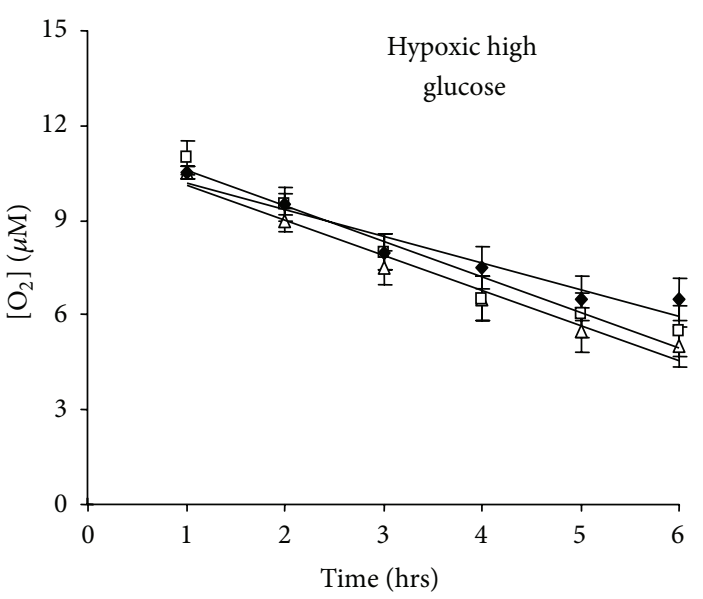

(f)

FIGURE 1: The depletion of oxygen within BD biosensor system containing C2C12 cells over a 6-hour culture period. The figures compare culture in low glucose (LG), medium glucose (MG), and high glucose (HG). The results are shown for $200 \mu \mathrm{L}$ cell samples of $0.5 \times 10^{5}$ cells $/ \mathrm{mL}$ $(\checkmark), 1 \times 10^{5}$ cells $/ \mathrm{mL}(\square)$, and $2 \times 10^{5}$ cells $/ \mathrm{mL}(\Delta)$ cultured with the appropriate medium exposed in normoxic ((a)-(c)) and hypoxic $((\mathrm{d})-(\mathrm{f}))$ environments. Each point represents the mean and standard deviation of six replicates. 


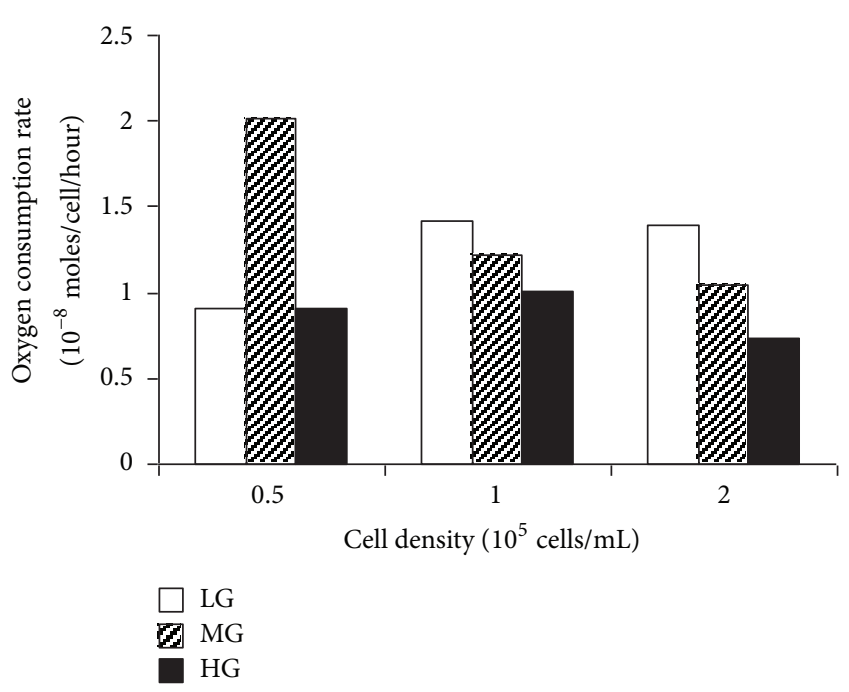

FIgURE 2: The initial oxygen consumption rate of $\mathrm{C} 2 \mathrm{C} 12$ cells cultured in LG, MG, and HG media at normoxic environment. Values are estimated from the linear region of the oxygen depletion curve, as indicated in Figures 1(a)-1(f).

3.3. Effect of Glucose Concentration and Hypoxia on the Metabolic Activity of C2C12 Cells. Alamar Blue assay was used to investigate the metabolic activity of $\mathrm{C} 2 \mathrm{C} 12$ cells after culture for $48 \mathrm{hrs}$ under different glucose and oxygen conditions (Figures 4 and 5). In Alamar Blue assay, a nonfluorescent substrate is converted to a fluorescent product by the activity of cellular enzymes. However, when this assay is used for cells growing in culture for long periods of time (days), an effect that causes an increase in cell number cannot be distinguished from an effect that increases individual cell activity (in both cases the fluorescent output will be increased); consequently, we carried out cell counts in parallel and attempted to normalise Alamar Blue assay results to contemporaneous cell counts (rather than the initial seeding density).

In normoxia, fluorescence produced in Alamar Blue assay was similar for all three densities of cells cultured in the LG condition but was proportional to cell density for cells cultured in either MH or HG condition (Figure 4(a)). Comparing cells grown at the same density but in different glucose concentrations, fluorescence tended to increase as the glucose concentration increased. Under hypoxia, the fluorescence generated by cells grown in LG condition was significantly lower than the equivalent cells in normoxia (Figure 4(c)). Cells grown in MG condition showed similar level of fluorescence in hypoxia and normoxia, whilst cells grown in HG condition showed greater level of fluorescence in hypoxia than that in normoxia (especially clear for cell density of $2 \times 10^{5}$ cells in high glucose, Figures $4(\mathrm{a})$ and $4(\mathrm{~b}))$. As for hypoxia condition, the greatest difference was seen between cells at a density of $0.5 \times$ $10^{5}$ cells $/ \mathrm{mL}$ where the normalized fluorescence for cells in MG condition was twofold higher than that in LG condition.
The effect of normalizing the Alamar Blue data presented in Figure 4 to contemporaneous cell counts was shown in Figure 5. In normoxia, there was a trend for the activity per cell to decrease as the glucose concentration increased, and this trend was most clear at densities of 1 and $2 \times 10^{5}$ cells/mL (Figures 5(a) and 5(d)). This suggested that the overall increase in fluorescence that occurs with the increase in glucose concentration before normalisation (Figure 4(a)), is due to an increase in cell number rather than an increase in individual cell activity. Indeed there is a suggestion that increasing glucose decreases individual cell activity. On the other hand, in hypoxia, activity per cell in low glucose condition was reduced compared to normoxia, whilst activities were similar for cells in medium and high glucose. Activity per cell tended to increase as the glucose concentration increased (Figure 5(b)), which is opposite to that found in normoxia (Figure 5(a)). It was supposed that under hypoxia the increase in fluorescence as glucose increased may be due to both an increase in cell number and an increase in the activity of each cell.

\section{Discussion}

The aim of this study was to understand the effect of glucose concentration and oxygen supply on oxygen depletion, glucose uptake, lactate production, and metabolic activity in $\mathrm{C} 2 \mathrm{C} 12$ cells, a murine skeletal myoblast cell line. It was found that, firstly, the rate of oxygen depletion was dependent on the glucose concentration in the culture medium in normoxia. Secondly, glucose uptake and lactate production increased in hypoxia; thirdly, with the increase in glucose concentration, metabolic activity decreased in normoxia, but increased in hypoxia; and finally, metabolic activity was reduced by hypoxia in LG and MG conditions, but unchanged in $\mathrm{HG}$ condition.

Arthur et al. [25] ever investigated the effect of hypoxia (5 $\mu \mathrm{M}$ oxygen) on $\mathrm{C} 2 \mathrm{C} 12$ cells and reported that this cell line responds to hypoxia by showing OC. However, our data did not support the occurrence of OC. Such disparity may be attributed to differences in study design between these two studies. Firstly, the time course selected in their study was $0-2$ hours, whereas we examined the responses for up to 72 hours, which should be more relevant to the general culture situation. Secondly, they employed a perfusion system to better control oxygen level but, unfortunately, created a condition, that is, not close to the normal culture situation, thus leading to a $10-20 \%$ loss of cell viability even over $1-2$ hours. It is quite possible that $\mathrm{OC}$ is an acute cell response to hypoxia, which does not persist over time. Alternatively, it is the gradual reduction (as applied by Arthur et al. [25]) not the step-change in oxygen level (employed in present study) that triggers OC. Contrary to this earlier study, our findings suggest that metabolic responses to hypoxia are greatly affected by glucose concentrations rather than oxygen availability.

Our findings demonstrated that $\mathrm{C} 2 \mathrm{C} 12$ cells respond to long-term hypoxia by increasing glucose consumption, 


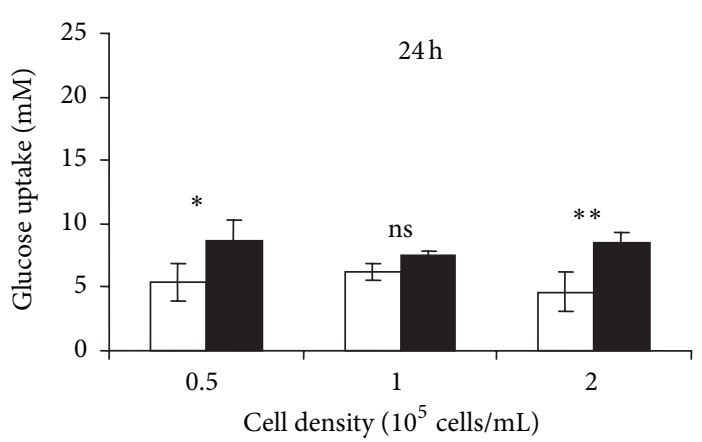

(a)

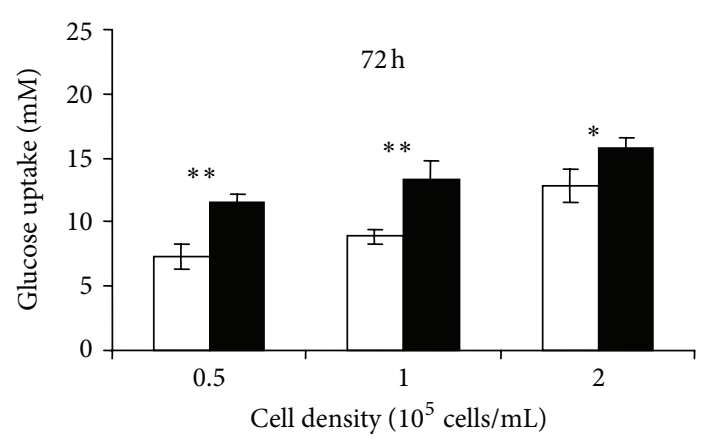

(c)

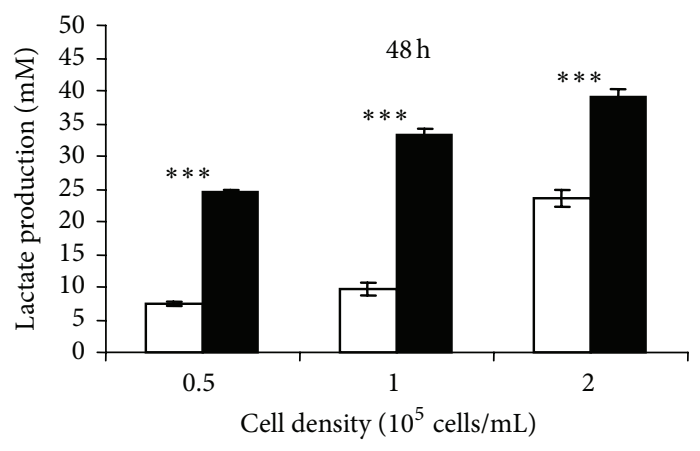

$\square$ Normoxic

a Hypoxic

(e)

)

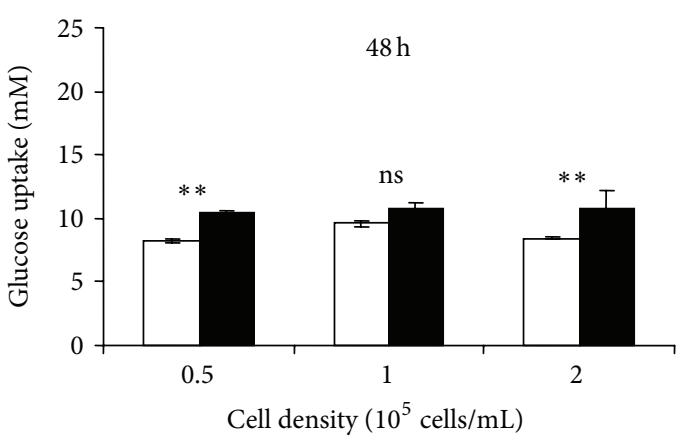

(b)

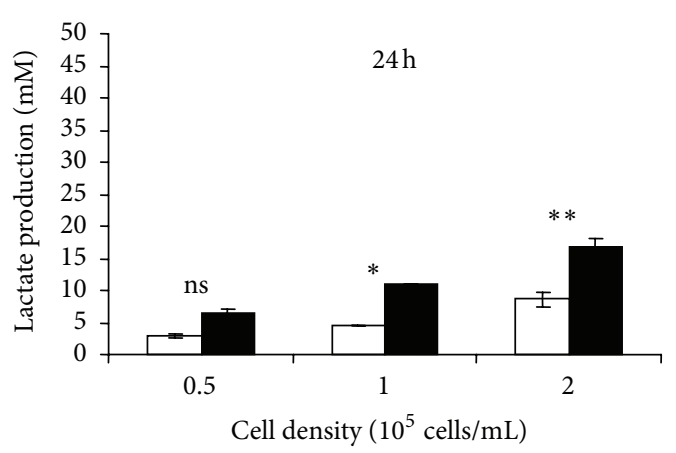

(d)

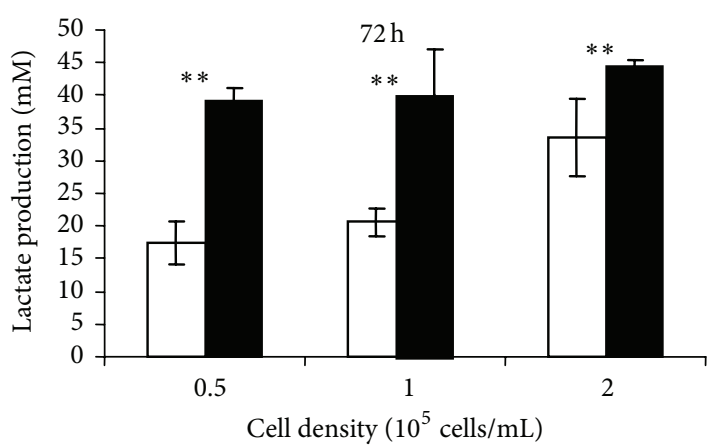

$\square$ Normoxic

- Hypoxic
(f)

Figure 3: Glucose uptake ((a)-(c)) and lactate production ((d)-(f)) of C2C12 cells cultured in HG medium at hypoxic and normoxic environments up to 72 hours period. Each bar represents the mean and standard deviation of six replicates. Comparisons of quantitative significant differences are shown in the figure, significance is indicated as nonsignificant, $P>0.05(\mathrm{~ns}), P<0.05\left(^{*}\right), P<0.01\left(^{* *}\right)$, and $\left.P<0.001{ }^{* * *}\right)$.

which indicates an increase in anaerobic respiration. OC was not observed in present study, which suggested that when there is sufficient glucose, $\mathrm{C} 2 \mathrm{C} 12$ cells will respond to hypoxia by up-regulating anaerobic respirations, as shown by lactate production. Metabolic activity was reduced when hypoxia was encountered in MG or LG but not reduced when cells experienced hypoxia in the presence of $\mathrm{HG}$, suggesting that a combination of low oxygen and low glucose damaged the viability of $\mathrm{C} 2 \mathrm{C} 12$ cells more seriously than low oxygen alone. Although cell density was shown to affect the magnitude of measured values, in most experiments, the same trend was observed at all three cell densities, suggesting that these results are not an artifact of the particular cell density studied.

In the present study, the oxygen consumption rate of $\mathrm{C} 2 \mathrm{C} 12$ cells in normoxia was around $3 \times 10^{-13}$ moles oxygen/hour/cell. This equates to an oxygen utilization rate (OUR) of 5 fmole $\min ^{-1}$ cell $^{-1}$, which was similar to those reported by Guarino et al. on a number of cell types [28]. Our results showed that oxygen consumption decreased as glucose concentration increased. There was an upregulation in oxygen consumption rate of cells cultured in LG and 


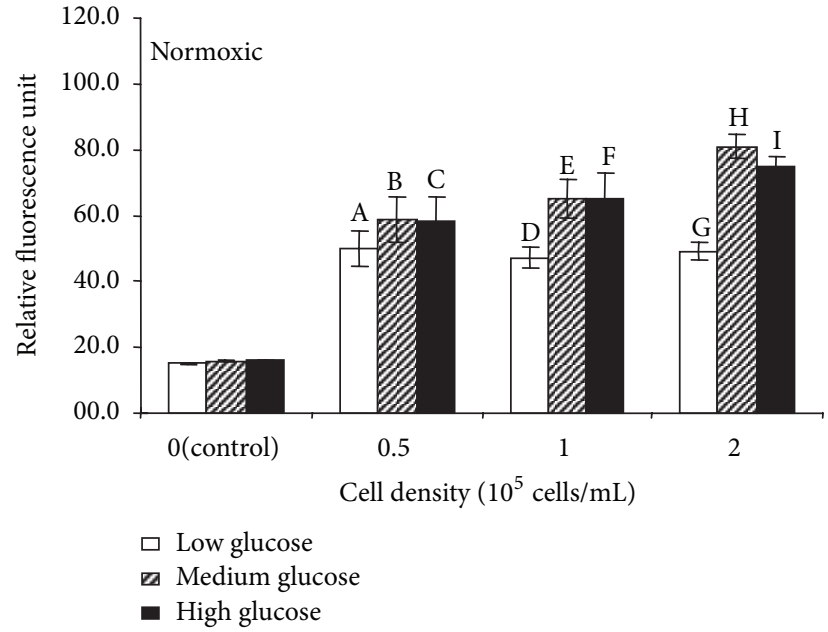

(a)

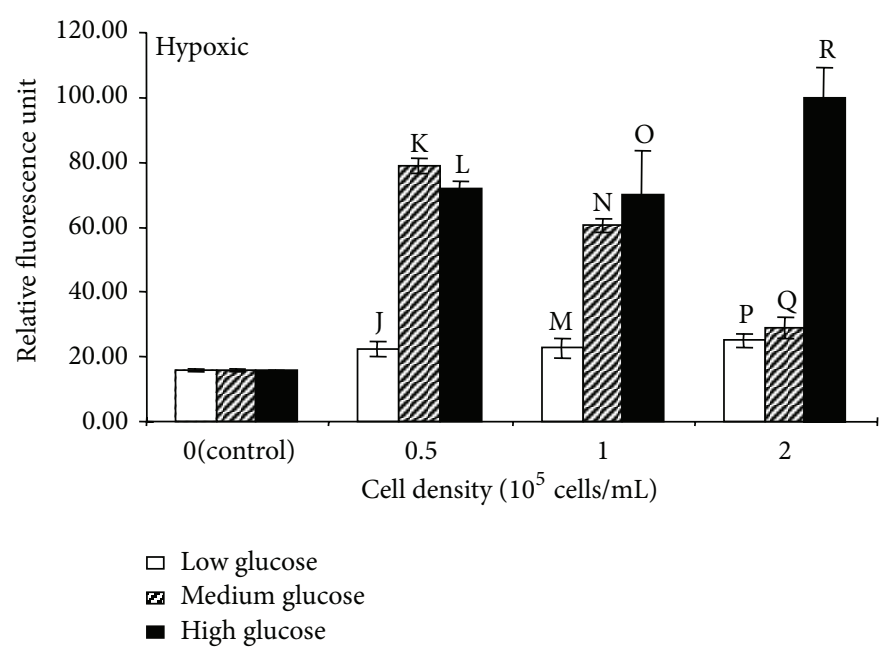

(b)

\begin{tabular}{|c|c|}
\hline Comparison of test groups & Relationship \\
\hline A versus J & $\mathrm{A}>\mathrm{J}^{* * *}$ \\
\hline B versus K & $\mathrm{B}<\mathrm{K}^{* * *}$ \\
\hline C versus L & $\mathrm{C}<\mathrm{L}^{* *}$ \\
\hline D versus M & $\mathrm{D}>\mathrm{M}^{* * *}$ \\
\hline E versus N & $\mathrm{ns}$ \\
\hline F versus O & $\mathrm{ns}$ \\
\hline G versus P & $\mathrm{G}>\mathrm{P}^{* * *}$ \\
\hline H versus $\mathrm{Q}$ & $\mathrm{H}>\mathrm{Q}^{* * *}$ \\
\hline I versus $\mathrm{I}$ & $\mathrm{I}<\mathrm{R}^{* * *}$ \\
\hline
\end{tabular}

(c)

Figure 4: Alamar Blue assay. Cellular metabolic states of C2C12 cells cultured with LG, MG, and HG media exposed at normoxic (a) and hypoxic (b) environment for 48 hours. Each bar represents the mean and standard deviation of eight replicates. Comparisons of quantitative significant differences are shown in the table (c) significance is indicated as $P<0.05\left({ }^{*}\right), P<0.01\left({ }^{* *}\right), P<0.001\left({ }^{* * *}\right)$, and nonsignificant, $P>0.05$ (ns).

MG compared to cells cultured in HG. This indicated that glucose concentration plays a key role in the shift of $\mathrm{C} 2 \mathrm{C} 12$ cell metabolic pathways. The anaerobic metabolism of $\mathrm{C} 2 \mathrm{C} 12$ cells was detected in HG culture with evidence of lactate production. Considerable increase in lactate production was found in the culture exposed to hypoxic environment compared to normoxic environment, suggesting a compensatory increase of anaerobic metabolism in hypoxia. The $\mathrm{C} 2 \mathrm{C} 12$ metabolic activity in LG culture exposed to hypoxic environment was found to be much lower than normoxic environment. The introduction of higher glucose concentrations (MG and HG) resulted in elevated cellular metabolic activity in hypoxic cultures, implicating glucose as the energy source for this activity.

There are some limitations to our study. Firstly, as mentioned in the Result Section, due to technical problem, oxygen consumption rates during hypoxia could not be measured using the oxygen biosensor plate as we did for normoxia. Secondly, Alamar Blue data were normalized to contemporaneous cell counts in order to eliminate the chance of confusing an alteration in cell number with an alteration in cell metabolism. However, the data after normalization (Figure 5) showed less consistency than that before normalization (Figure 4). This was most likely due to difficulties in detaching and counting cells in the small wells of the 96-well plate, which may be resolved using other counting strategies in the future.

\section{Conclusions}

In this study, the aerobic and anaerobic respirations in $\mathrm{C} 2 \mathrm{C} 12$ murine skeletal myoblasts were investigated by measuring 


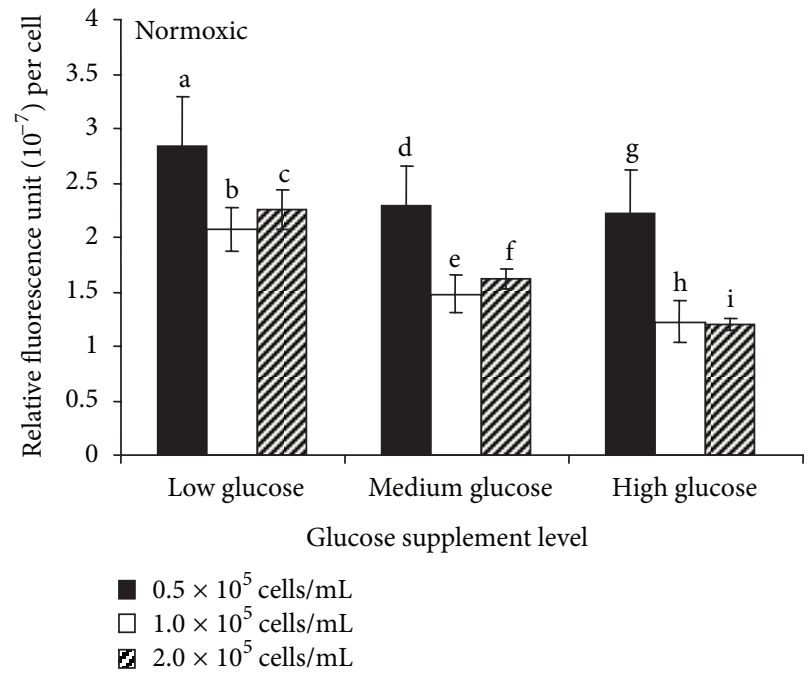

(a)

\begin{tabular}{|l|c|}
\hline $\begin{array}{c}\text { Comparison } \\
\text { of normoxic } \\
\text { groups versus } \\
\text { hypoxic } \\
\text { groups }\end{array}$ & Relationship \\
\hline a versus $j$ & $\mathrm{a}>\mathrm{j}^{* * *}$ \\
\hline b versus $\mathrm{k}$ & $\mathrm{b}>\mathrm{k}^{* * *}$ \\
\hline c versus $\mathrm{l}$ & $\mathrm{c}>\mathrm{l}^{* * *}$ \\
\hline d versus $\mathrm{m}$ & $\mathrm{d}<\mathrm{m}^{* * *}$ \\
\hline e versus $\mathrm{n}$ & $\mathrm{ns}$ \\
\hline f versus o & $\mathrm{f}>\mathrm{o}^{* * *}$ \\
\hline g versus $\mathrm{p}$ & $\mathrm{ns}$ \\
\hline $\mathrm{h}$ versus $\mathrm{q}$ & $\mathrm{ns}$ \\
\hline i versus $\mathrm{r}$ & $\mathrm{i}<\mathrm{r}^{* * *}$ \\
\hline
\end{tabular}

(c)

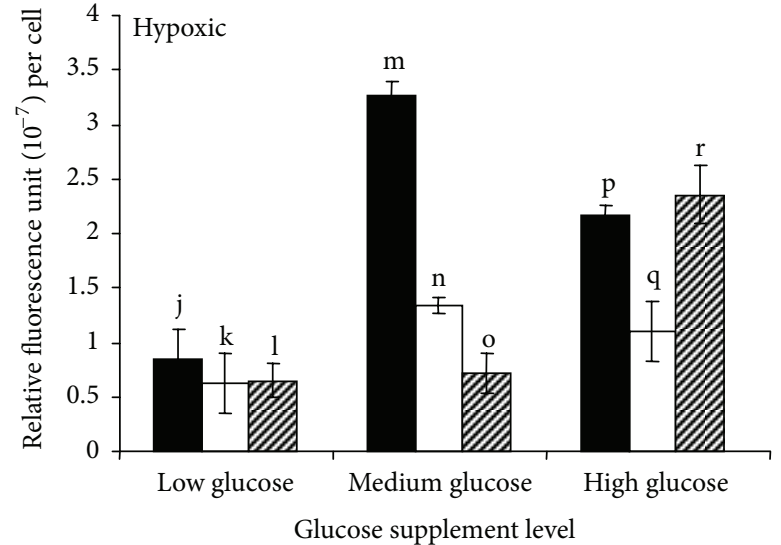

$0.5 \times 10^{5}$ cells $/ \mathrm{mL}$

$\square 1.0 \times 10^{5} \mathrm{cells} / \mathrm{mL}$

(2) $2.0 \times 10^{5}$ cells $/ \mathrm{mL}$

(b)

\begin{tabular}{|l|l|}
\hline $\begin{array}{c}\text { Comparison of } \\
\text { different } \\
\text { glucose } \\
\text { supplement } \\
\text { medium } \\
\text { groups }\end{array}$ & Relationship \\
\hline a versus $\mathrm{d}$ & $\mathrm{ns}$ \\
\hline a versus g & $\mathrm{ns}$ \\
\hline $\mathrm{d}$ versus $\mathrm{g}$ & $\mathrm{ns}$ \\
\hline $\mathrm{j}$ versus $\mathrm{m}$ & $\mathrm{J}<\mathrm{m}^{* * *}$ \\
\hline $\mathrm{j}$ versus $\mathrm{p}$ & $\mathrm{j}<\mathrm{p}^{* * *}$ \\
\hline $\mathrm{m}$ versus $\mathrm{p}$ & $\mathrm{m}>\mathrm{p}^{* * *}$ \\
\hline $\mathrm{b}$ versus $\mathrm{e}$ & $\mathrm{b}>\mathrm{e}^{* *}$ \\
\hline $\mathrm{b}$ versus $\mathrm{h}$ & $\mathrm{b}>\mathrm{h}^{* * *}$ \\
\hline $\mathrm{e}$ versus $\mathrm{h}$ & $\mathrm{ns}$ \\
\hline $\mathrm{k}$ versus $\mathrm{n}$ & $\mathrm{k}<\mathrm{n}^{* *}$ \\
\hline $\mathrm{k}$ versus $\mathrm{q}$ & $\mathrm{k}<\mathrm{q}^{*}$ \\
\hline $\mathrm{n}$ versus $\mathrm{q}$ & $\mathrm{ns}^{* * *}$ \\
\hline $\mathrm{c}$ versus $\mathrm{f}$ & $\mathrm{c}>\mathrm{f}^{* * *}$ \\
\hline $\mathrm{c}$ versus $\mathrm{i}$ & $\mathrm{c}>\mathrm{i}^{* * *}$ \\
\hline $\mathrm{f}$ versus $\mathrm{i}$ & $\mathrm{f}>\mathrm{i}^{* *}$ \\
\hline $\mathrm{l}$ versus $\mathrm{o}$ & $\mathrm{ns}^{*}$ \\
\hline $\mathrm{lversus} \mathrm{r}$ & $\mathrm{l}<\mathrm{r}^{* * *}$ \\
\hline o versus $\mathrm{r}$ & $\mathrm{o}<\mathrm{r}^{* * *}$ \\
\hline
\end{tabular}

(d)

FIGURE 5: Cellular metabolic state of each C2C12 cell in different cell densities $\left(0.5 \times 10^{5}\right.$ cells $/ \mathrm{mL}, 1 \times 10^{5}$ cells $/ \mathrm{mL}$ and $2 \times 10^{5}$ cells $\left./ \mathrm{mL}\right)$, and in different glucose supplement media (LG, MG and HG) culture exposed at normoxic (a) and hypoxic (b) environments for 48 hours. Comparisons of quantitative significant differences are shown in the table (c) significance is indicated as $P<0.05\left(^{*}\right), P<0.01\left(^{* *}\right), P<0.001$ $\left({ }^{* * *}\right)$, and nonsignificant, $P>0.05(\mathrm{~ns})$.

oxygen consumption, glucose consumption, lactate production, and metabolic activity in different glucose concentrations, under conditions of normoxia and hypoxia. Our findings suggest that a combination of low oxygen and low glucose damages the viability of $\mathrm{C} 2 \mathrm{C} 12$ cells more seriously than low oxygen alone. In addition, when there is sufficient glucose $\mathrm{C} 2 \mathrm{C} 12$ cells will respond to hypoxia by upregulating anaerobic respiration, as shown by lactate production.

\section{Abbreviations}

OC: $\quad$ Oxygen conformance

ATP: Adenosine- $5^{\prime}$-triphosphate

atm: Atmosphere

LG: Low-glucose

MG: Medium glucose

HG: High glucose

OUR: Oxygen utilization rate

EM: Experiment media. 


\section{Conflict of Interests}

The authors declare that there is no conflict of interests of any kind in this research.

\section{Authors' Contribution}

Wei Li was responsible for the study design. Wei Li and Zhen$\mathrm{Fu} \mathrm{Hu}$ conducted the experiments. Bin Chen performed the statistical analysis. Guo-Xin Ni prepared the paper. All authors read and approved the final manuscript. Wei Li and Zhen-Fu Hu contributed equally in this work.

\section{Acknowledgments}

This project was partially supported by Guangdong Province Natural Science Fund (9151051501000075), Guangdong Province Natural Science Fund (S2011020003140), and special funding for university talent introduction of Guangdong Province (Guo-Xin Ni).

\section{References}

[1] B. A. Mizock and J. L. Falk, "Lactic acidosis in critical illness," Critical Care Medicine, vol. 20, no. 1, pp. 80-93, 1992.

[2] N. Paquot, P. Schneiter, M. C. Cayeux et al., "Effects of infused sodium lactate on glucose and energy metabolism in healthy humans," Diabete et Metabolisme, vol. 21, no. 5, pp. 345-352, 1995.

[3] K. S. Saladin, Anatomy and Physiology: The Unity of Form and Function, McGraw-Hill, New York, NY, USA, 3rd edition, 2004.

[4] P. Hochachka and M. Guppy, Arrest and Control of Biological Time, Harvard University Press, Cambridge, Mass, USA, 1987.

[5] E. Gnaiger, "Oxygen conformance of cellular respiration: a perspective of mitochondrial physiology," Advances in Experimental Medicine and Biology, vol. 543, pp. 39-55, 2003.

[6] M. C. Hogan, S. S. Kurdak, and P. G. Arthur, "Effect of gradual reduction in $\mathrm{O}_{2}$ delivery on intracellular homeostasis in contracting skeletal muscle," Journal of Applied Physiology, vol. 80, no. 4, pp. 1313-1321, 1996.

[7] G. R. S. Budinger, N. Chandel, Z. H. Shao et al., "Cellular energy utilization and supply during hypoxia in embryonic cardiac myocytes," The American Journal of Physiology, vol. 270, no. 1, pp. L44-L53, 1996.

[8] R. M. Subramanian, N. Chandel, G. R. Scott Budinger, and P. T. Schumacker, "Hypoxic conformance of metabolism in primary rat hepatocytes: a model of hepatic hibernation," Hepatology, vol. 45 , no. 2, pp. 455-464, 2007.

[9] L. G. Forgan and M. E. Forster, "Oxygen consumption and blood flow distribution in perfused skeletal muscle of chinook salmon," Journal of Comparative Physiology B, vol. 179, no. 3, pp. 359-368, 2009.

[10] V. Andrés and K. Walsh, "Myogenin expression, cell cycle withdrawal, and phenotypic differentiation are temporally separable events that precede cell fusion upon myogenesis," Journal of Cell Biology, vol. 132, no. 4, pp. 657-666, 1996.

[11] T. Shimokawa, M. Kato, O. Ezaki, and S. Hashimoto, "Transcriptional regulation of muscle-specific genes during myoblast differentiation," Biochemical and Biophysical Research Communications, vol. 246, no. 1, pp. 287-292, 1998.
[12] M. A. Lawson and P. P. Purslow, "Differentiation of myoblasts in serum-free media: effects of modified media are cell linespecific," Cells Tissues Organs, vol. 167, no. 2-3, pp. 130-137, 2000.

[13] I. Delgado, X. Huang, S. Jones et al., "Dynamic gene expression during the onset of myoblast differentiation in vitro," Genomics, vol. 82, no. 2, pp. 109-121, 2003.

[14] X. Shen, J. M. Collier, M. Hlaing et al., "Genome-wide examination of myoblast cell cycle withdrawal during differentiation," Developmental Dynamics, vol. 226, no. 1, pp. 128-138, 2003.

[15] S. Burattini, R. Ferri, M. Battistelli, R. Curci, F. Luchetti, and E. Falcieri, "C2C12 murine myoblasts as a model of skeletal muscle development: Morpho-functional characterization," European Journal of Histochemistry, vol. 48, no. 3, pp. 223-233, 2004.

[16] N. S. Tannu, V. K. Rao, R. M. Chaudhary et al., "Comparative proteomes of the proliferating $\mathrm{C} 2 \mathrm{C} 12$ myoblasts and fully differentiated myotubes reveal the complexity of the skeletal muscle differentiation program," Molecular and Cellular Proteomics, vol. 3, no. 11, pp. 1065-1082, 2004.

[17] P. Veliça and C. M. Bunce, "A quick, simple and unbiased method to quantify $\mathrm{C} 2 \mathrm{C} 12$ myogenic differentiation," Muscle and Nerve, vol. 44, no. 3, pp. 366-370, 2011.

[18] L. Zhang, S. Shi, J. Zhang, F. Zhou, and P. Ten Dijke, "Wnt/ $\beta$ catenin signaling changes $\mathrm{C} 2 \mathrm{C} 12$ myoblast proliferation and differentiation by inducing Id3 expression," Biochemical and Biophysical Research Communications, vol. 419, no. 1, pp. 83-88, 2012.

[19] T. Okano and T. Matsuda, "Tissue engineered skeletal muscle: preparation of highly dense, highly oriented hybrid muscular tissues," Cell Transplantation, vol. 7, no. 1, pp. 71-82, 1998.

[20] R. G. Dennis and P. E. Kosnik II, "Excitability and isometric contractile properties of mammalian skeletal muscle constructs engineered in vitro," In Vitro Cellular and Developmental Biology, vol. 36, no. 5, pp. 327-335, 2000.

[21] R. G. Dennis, P. E. Kosnik II, M. E. Gilbert, and J. A. Faulkner, "Excitability and contractility of skeletal muscle engineered from primary cultures and cell lines," The American Journal of Physiology, vol. 280, no. 2, pp. C288-C295, 2001.

[22] R. Srikakulam and D. A. Winkelmann, "Chaperone-mediated folding and assembly of myosin in striated muscle," Journal of Cell Science, vol. 117, no. 4, pp. 641-652, 2004.

[23] D. Gawlitta, W. Li, C. W. J. Oomens, F. P. T. Baaijens, D. L. Bader, and C. V. C. Bouten, "The relative contributions of compression and hypoxia to development of muscle tissue damage: an in vitro study," Annals of Biomedical Engineering, vol. 35, no. 2, pp. 273-284, 2007.

[24] W.-Y. Lee, W.-Y. Cheng, Y.-C. Yeh et al., "Magnetically directed self-assembly of electrospun superparamagnetic fibrous bundles to form three-dimensional tissues with a highly ordered architecture," Tissue Engineering C, vol. 17, no. 6, pp. 651-661, 2011.

[25] P. G. Arthur, J. J. Giles, and C. M. Wakeford, "Protein synthesis during oxygen conformance and severe hypoxia in the mouse muscle cell line C2C12," Biochimica et Biophysica Acta, vol. 1475, no. 1, pp. 83-89, 2000.

[26] D. Gawlitta, C. W. J. Oomens, D. L. Bader, F. P. T. Baaijens, and C. V. C. Bouten, "Temporal differences in the influence of ischemic factors and deformation on the metabolism of engineered skeletal muscle," Journal of Applied Physiology, vol. 103, no. 2, pp. 464-473, 2007.

[27] H. K. Heywood, D. L. Bader, and D. A. Lee, "Rate of oxygen consumption by isolated articular chondrocytes is sensitive to 
medium glucose concentration," Journal of Cellular Physiology, vol. 206, no. 2, pp. 402-410, 2006.

[28] R. D. Guarino, L. E. Dike, T. A. Haq, J. A. Rowley, J. B. Pitner, and M. R. Timmins, "Method for determining oxygen consumption rates of static cultures from microplate measurements of pericellular dissolved oxygen concentration," Biotechnology and Bioengineering, vol. 86, no. 7, pp. 775-787, 2004. 

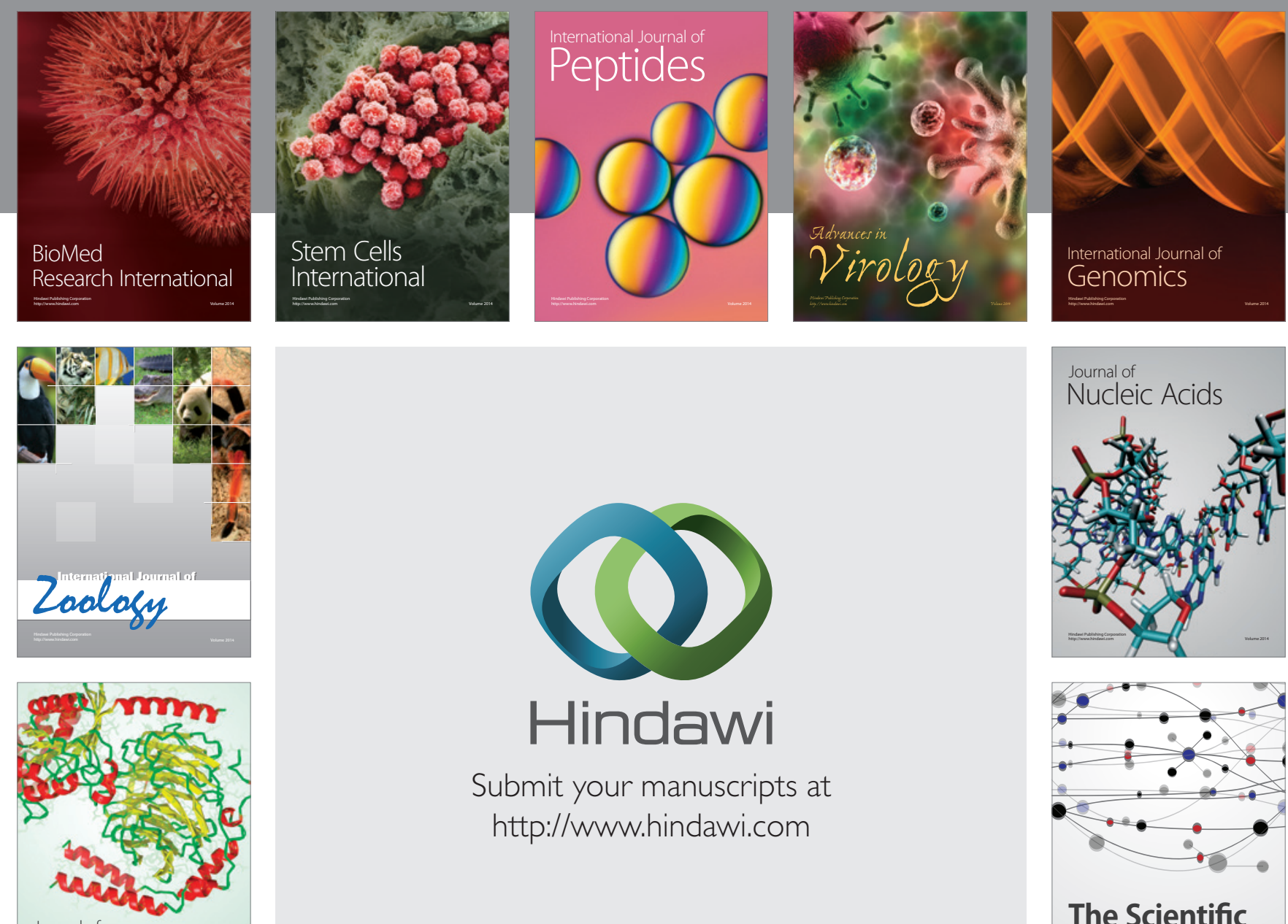

Submit your manuscripts at

http://www.hindawi.com

Journal of
Signal Transduction
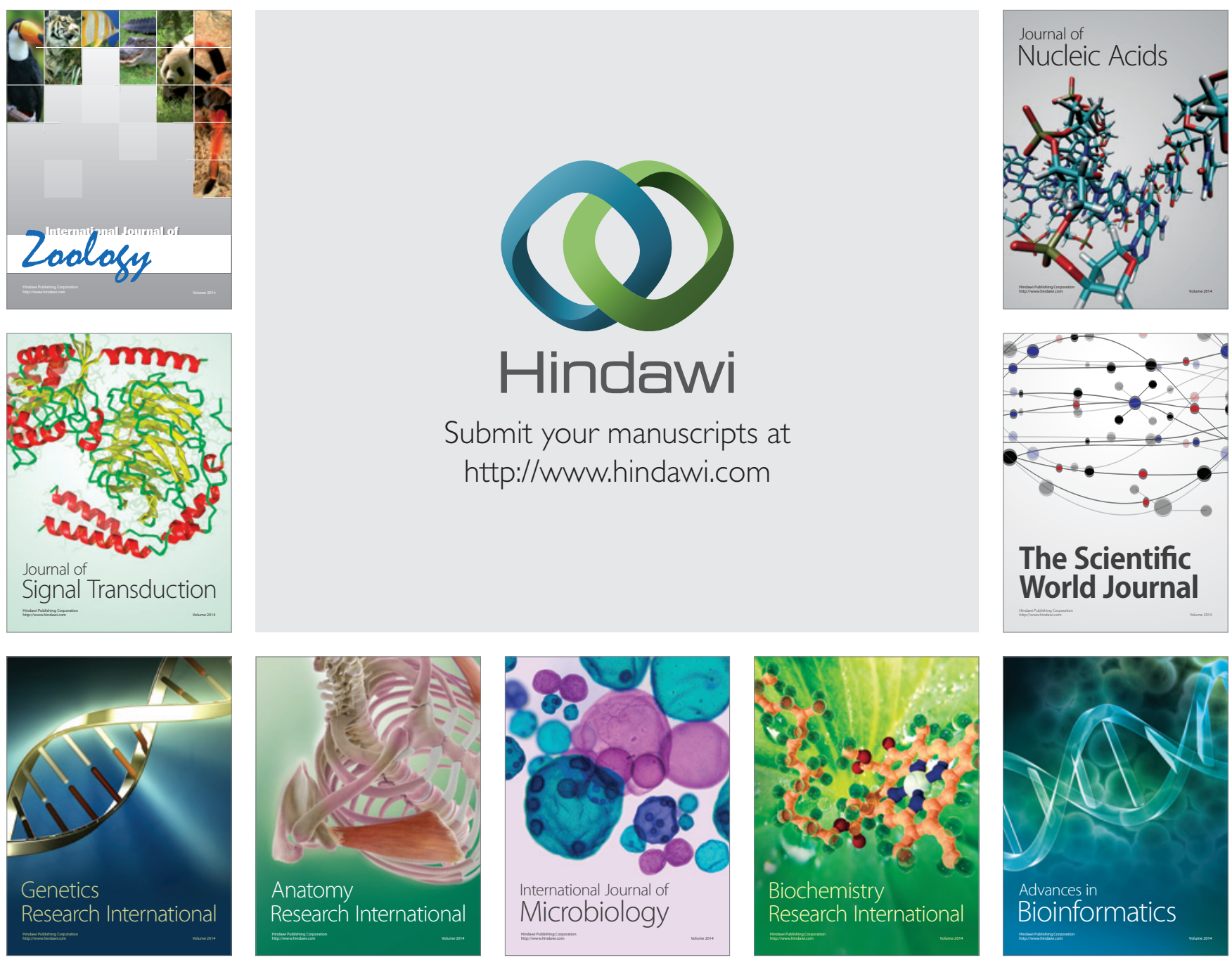

The Scientific World Journal
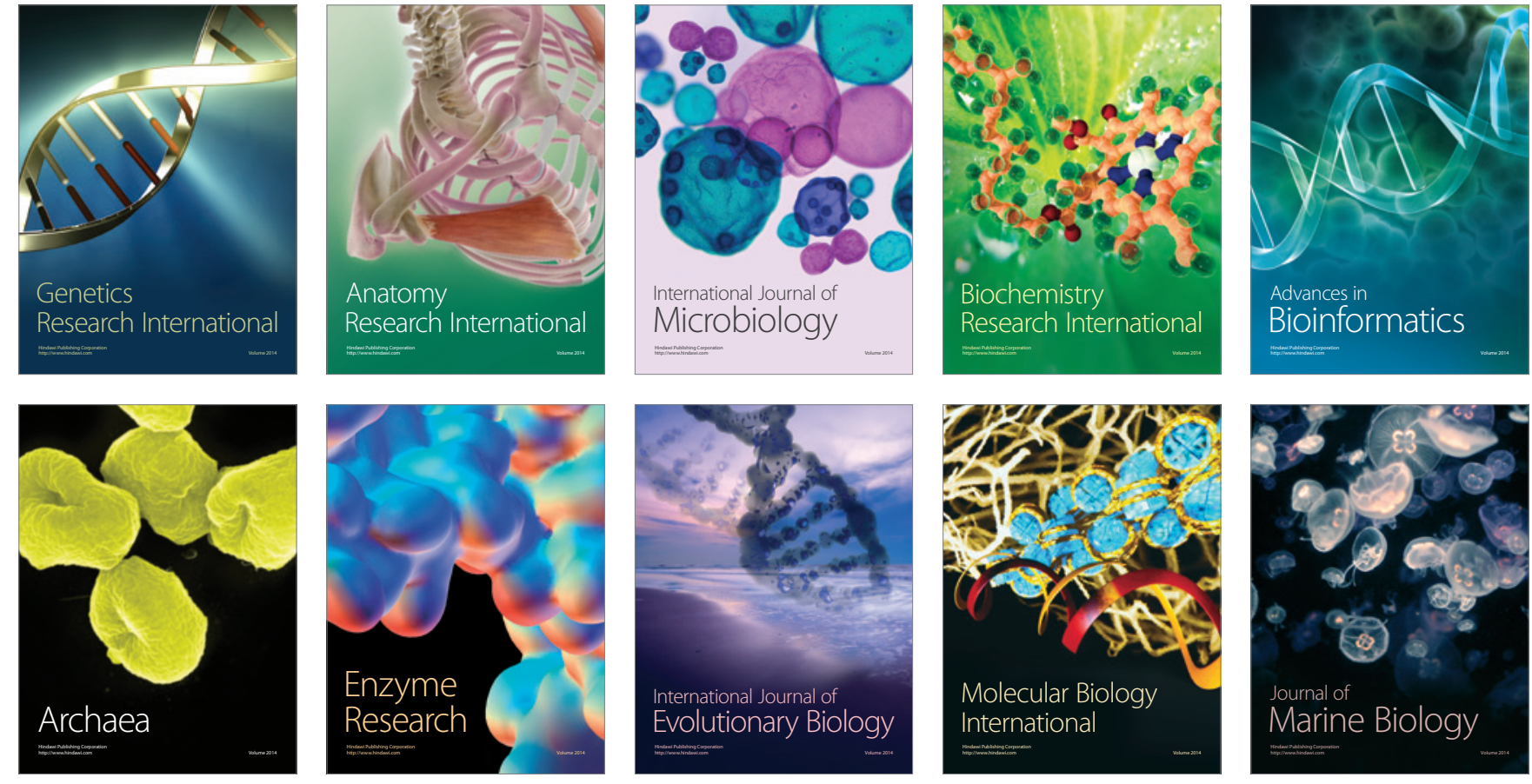